\title{
Hereditary Aspects of Duodenal Ulceration: Serum-pepsinogen Level in Relation to ABO Blood Groups and Salivary ABH Secretor Status
}

\author{
W. B. HANLEY,* M.D., M.R.C.P.
}

Brit. med.F., 1964, 1, 936-940

The association of duodenal ulcer with blood group $O$ (Aird et al., 1954 ; Roberts, 1957) and with salivary ABH nonsecretion (Clarke et al., 1956 ; Doll et al., 1961) is firmly established. Thus the family studies of Doll and Kellock (1951), which showed evidence of a hereditary factor in duodenal ulcer, have been substantiated by identification of two of the responsible genetic loci-namely, those for the genes determining ABO blood group and salivary $\mathrm{ABH}$ secretor status. Though the underlying mechanisms whereby these genes influence liability to duodenal ulcer remain somewhat obscure, yet the present paper throws some light on one facet of the problem.

Sievers (1959), using the "diagnex" blue test as a screening procedure for "achlorhydria" in several hundred patients, found evidence of free acid in $86.1 \%$ of group $O$ patients but in only $73.0 \%$ of group A patients. Similarly, using the serum-pepsinogen level as an index of gastric secretion, Sievers found a significantly higher mean level in group $O$ than in group A patients. These findings suggest the possibility that the possession of group $O$ phenotype leads to the development of a greater gastric-acid-pepsin secretory-cell mass than that in the other ABO blood-group phenotypes. Further support for this possibility exists in the work of Purohit and Shukla (1960), who related the mean acid output in response to an alcohol test meal to the ABO blood groups, and in the clinical evidence, wherein there is not only decreasing gastric acidity but also a gradual switch from preponderance, relative to the control population, of group $\mathrm{O}$ to that of group $\mathrm{A}$, in the following series of conditions-duodenal ulcer, gastric ulcer, gastric cancer, and pernicious anaemia (Køster et al., 1955).

While the present study was in progress Niederman et al. (1962), in a survey of 1,000 university intake students, stated that they found no significant differences between the mean serum-pepsinogen levels of the various ABO blood group and salivary $\mathrm{ABH}$ secretor phenotypic classes. Nevertheless, the mean level was higher in group $\mathrm{O}$ salivary $\mathrm{ABH}$ non-secretors than in group $A$ salivary $A B H$ secretors $(P<0.2)$. For the following reasons it is felt that the negative results of Niederman et al. (1962) cannot be fully accepted. (1) They studied a younger age-group of 16-21 years. It may be that, because the gastric secretory mass was still not fully developed, the potential differences between the phenotypes had not yet become apparent. (2) Comparison of the standard deviations for the data in the different phenotypic classes shows a disturbingly wide range of variation, from 77 to 155 . (3) They conducted statistical analysis on material with a skew distribution.

Similarly, the work of Sievers (1959) is open to the criticism that it was conducted on patients rather than the healthy population, even though diseases known to influence gastric secretion were excluded.

The present study is an investigation into the relation between the serum-pepsinogen level in healthy young male and female adults and the $\mathrm{ABO}$ blood group and salivary $\mathrm{ABH}$ secretor phenotypes. To facilitate statistical analysis, the number of subjects in each phenotypic class has been kept equal. Because

\footnotetext{
* Department of Medicine, University of Liverpool.
}

of the difficulty in obtaining large numbers of group $B$ and $A B$ salivary $A B H$ non-secretors, only groups $O$ and $A$ have been studied. While there is no method available for directly measuring the gastric peptic-cell mass comparable to the Kay (1953) test for parietal-cell mass, Spiro et al. (1956) and Ronsky and Skala (1961) reported significant correlation between gastric pepsin secretion after histamine and the serum-pepsinogen level. Similarly, Hirschowitz (1955) and Goidsenhoven et al. (1958) found correlation between the means of repeated basal estimates of acid and pepsin secretion and the serum-pepsinogen level. It thus seems likely that the latter affords an index of the gastric peptic-cell mass (Hirschowitz, 1955). Because under most conditions the output of acid and that of pepsin are roughly parallel (Spiro et al., 1956), it may be presumed with a fair degree of confidence that the serum-pepsinogen level reflects the size of the gastric secretory-cell mass (in this article the term " gastric secretory-cell mass" refers to the parietal and peptic cells but excludes the mucus-secreting cell mass).

\section{Material and Methods}

Large numbers of healthy individuals aged 18 to 35 inclusive from the population were screened in order that the serumpepsinogen level of the 100 subjects could be determined in each of eight phenotypic classes (male and female, blood group $O$ and $\mathrm{A}$, salivary $\mathrm{ABH}$ secretor and non-secretor) making a total of 800 subjects. In all, over 2,000 healthy individuals within the age limits of 18 to 35 years were blood-grouped and tested for salivary $\mathrm{ABH}$ secretor status. Initially volunteer medical students, nurses, and ancillary hospital staff were studied, but it became necessary to utilize the facilities of the Liverpool Regional Blood Transfusion Service in order to achieve the target of 100 subjects per phenotypic class.

Approximately 10-15 ml. of blood was taken from each volunteer and serum obtained by centrifugation after two to six hours at room temperature. The serum was frozen at $-20^{\circ}$ C. until assayed for pepsinogen content. The clotted red cells were stored at 3 to $5^{\circ} \mathrm{C}$. until blood-grouped by standard tube technique within four days of collection.

Saliva was obtained without artificial secretory aid. The salivary ABH secretor status of the individual was determined by a standard method (see Clarke et al., 1956).

Factors eliminating a volunteer from the survey were: (1) blood group known to be $\mathrm{B}$ or $\mathrm{AB}$; (2) blood relationship to a person already included ; (3) a past or present history of peptic ulcer, dyspepsia, diabetes mellitus, or any other chronic illness ; (4) a history of renal disease, as nitrogen retention, if present, would falsely elevate the serum pepsinogen.

The method of serum-pepsinogen assay used in this work (Hanley, 1963) was developed from that described by Sievers and Fischer (1957). It is felt to represent an improvement on the existing methods. (a) A buffer system is incorporated, allowing flexible control of the $p \mathrm{H}$ of the incubation mixture, without significant variations in the ionic strength of the solution. (b) Precipitated protein is removed by centrifugation. 
The use of filter paper results in a variable gain in chromogenic material in the trichloracetic acid filtrate. (c) The FolinCiocalteu colour reaction is developed by the use of $4 \%$ anhydrous sodium carbonate in $0.1 \mathrm{~N}$ sodium hydroxide instead of $0.5 \mathrm{~N}$ sodium hydroxide, plus incubation for 30 minutes at $37^{\circ} \mathrm{C}$. This results in a greater intensity of colour, which is also stable over 30 minutes.

The serum-pepsinogen level has been taken as the number of micrograms of tyrosine, equivalent in optical density (with Folin-Ciocalteu reagent) to that optical density released by $1 \mathrm{ml}$. of serum during 24 hours of incubation, for the particular assay conditions. No allowance has been made for that optical density released by non-enzymic acid hydrolysis of the haemoglobin substrate and the serum protein of the test serum. Thus the serum-pepsinogen level is some $30 \mu \mathrm{g}$. above the true figures, but as variations in the magnitude of this non-enzymic faction are small, the overall results are not materially affected.

The following facts were verified: (1) The serum pepsinogen is stable at $-20^{\circ} \mathrm{C}$. for up to six months. Thereafter some decrease in activity seems to occur (see Fig. 1). (2) The length

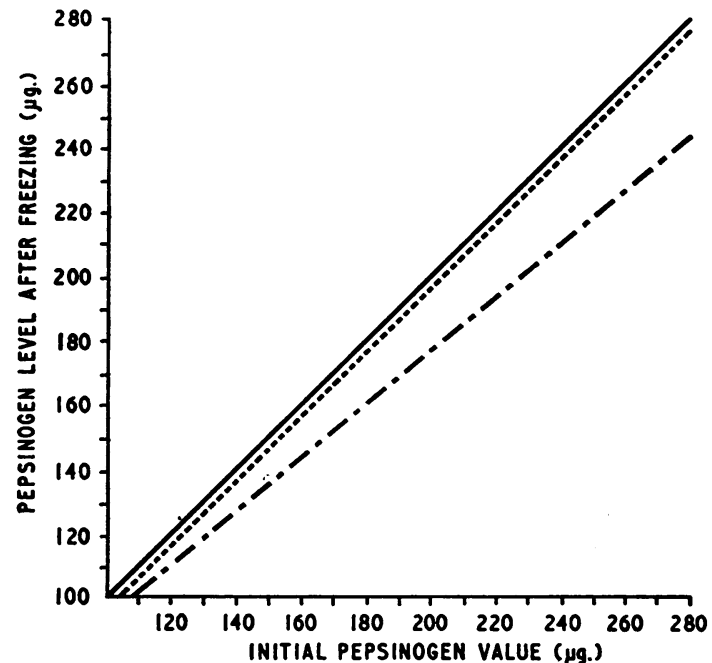

FIG. 1.-Effect of prolonged freezing at $-20^{\circ}$ C. on the serum-pepsinogen level. Pepsinogen level of sera frozen

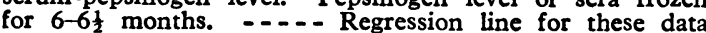
(regression coefficient $=0.97$ ) . Pepsinogen level of sera (regresinogen level of sera frozen for 10-13 months. - - - Regression line for these data (regression coefficient $=0.81$ ). Theoretical regression line if no deterioration occurred with freezing. Comparison of the above regression coefficients showed no significant difference $(t=1.48$; d.o.f. $25 ; P>0.1)$, but never theless the data are felt to reflect a decrease in serumpepsinogen activity in sera frozen for 10-13 months, but not for serum frozen for $6-6 \frac{1}{2}$ months.

of time, up to eight hours, elapsing before separation of the serum does not influence the serum-pepsinogen level. Five specimens of serum from the same blood sample, but separated from the clot at varying intervals between one-and-a-half and eight hours, showed no difference in pepsinogen level. (3) The use of venous occlusion as an aid to blood-collection does not Influence the serum-pepsinogen level. In the four subjects studied the pepsinogen concentration in the serum was not significantly different in blood samples taken before and after 15 minutes of venous occlusion.

\section{Results}

The assay has been performed in duplicate for each specimen of serum.

The frequency distribution of serum pepsinogen in normal subjects is skew but $\log _{10}$ distribution is normal. $\log _{10}$ values have therefore been used for all computations. Figs. 2 and 3 show the $\log _{10}$ cumulative frequency distribution in the different phenotypic classes in males and females respectively.
Table I shows the mean $\log _{10}$ serum-pepsinogen level together with the standard error of the mean for each phenotypic class. It is obvious that when other things are equal the mean value is higher in males than in females, in $O$ than in $A$, and in nonsecretors than in secretors (the only exception being female $O$ secretor to female $\mathrm{O}$ non-secretor).

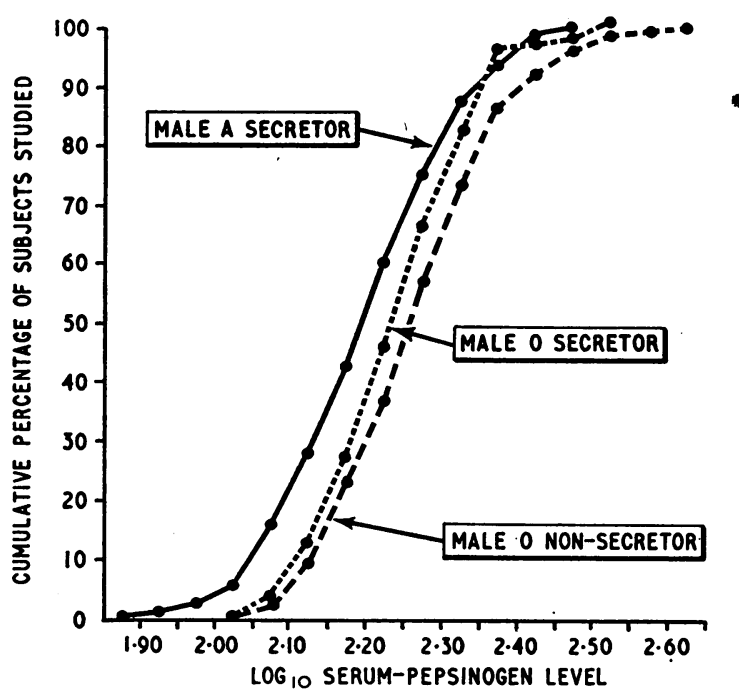

Fig. 2.-Cumulative frequency distribution of $\log _{10}$ serumpepsinogen levels in each of group $O$ male non-secretor group $O$ male secretor, and group $A$ male secretor phenotypic classes (100 subjects in each). That for group A nonsecretor is intermediate between group $\mathrm{A}$ secretor and group $O$ secretor, and is omitted for the sake of clarity.

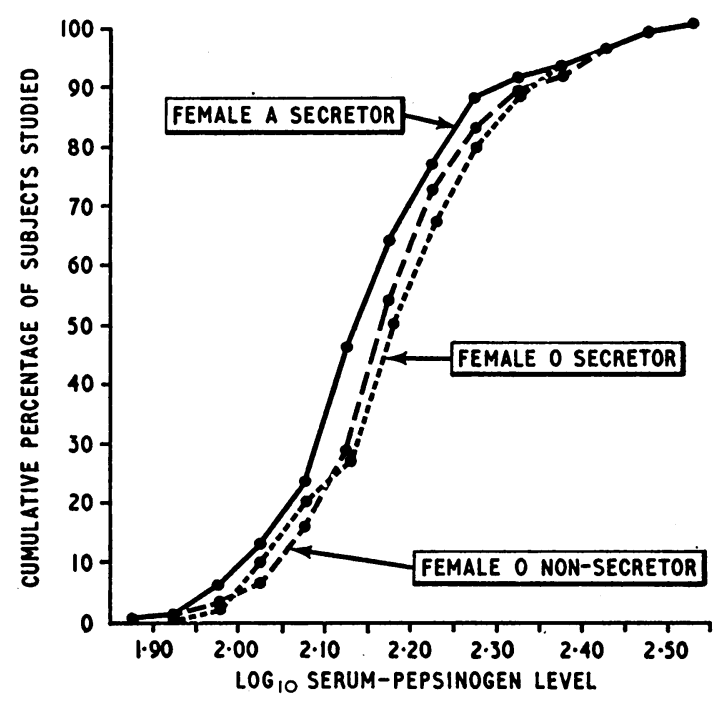

FIG. 3:-Cumulative frequency distribution of $\log _{1}$ serumpepsinogen levels in each of group $O$ female non-secretor,
group $O$ female secretor, and group $A$ female secretor group $O$ female secretor, and group A female secretor
phenotypic classes (100 subjects in each). That for group A non-secretor is intermediate between group A secretor and group $O$ non-secretor, and is omitted for the sake of clarity.

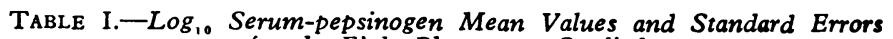
for the Eight Phenotypes Studied

\begin{tabular}{c|c|c|c|c|c}
\hline $\begin{array}{c}\text { Blood } \\
\text { Group }\end{array}$ & $\begin{array}{c}\text { Secretor } \\
\text { Status }\end{array}$ & Sex & $\begin{array}{c}\text { No. of } \\
\text { Subjects }\end{array}$ & Mean & S. Em. \\
\hline O & S & M & 100 & $2 \cdot 2539$ & 0.0093 \\
A & S & M & 100 & $2 \cdot 2174$ & 0.0109 \\
A & ss & M & 100 & 2.2837 & 0.0110 \\
\hline O. & S & F & 100 & $2 \cdot 2278$ & 0.0113 \\
A & S & F & 100 & $2 \cdot 1722$ & 0.0119 \\
A & ss & F & 100 & $2 \cdot 1936$ & 0.0119 \\
& ss & F & 100 & 2.1906 & 0.0128 \\
\hline
\end{tabular}

$\mathrm{S}=$ Secretor. $\mathrm{ss}=$ Non-secretor. S. Em. $=$ Standard error of mean. 
The number of subjects in each phenotypic class has deliberately been made equal, and it is thus possible, by an analysis of variance, to compare separately the effect of blood group, secretor status, and sex on the serum-pepsinogen level (see Table II). The analysis incorporates the full 1,600 serumpepsinogen estimations, the assay having been performed in duplicate for each specimen of serum.

TABLE II.-Analysis of Variance of the logio Serum-pepsinogen Data

\begin{tabular}{|c|c|c|c|c|c|}
\hline Item & $\begin{array}{c}\text { Sum } \\
\text { of } \\
\text { Squares }\end{array}$ & $\begin{array}{l}\text { Degrees } \\
\text { of } \\
\text { Freedom }\end{array}$ & $\begin{array}{l}\text { Mean } \\
\text { Square }\end{array}$ & $\begin{array}{l}\text { Variance } \\
\text { Ratio }\end{array}$ & $\mathbf{P}$ \\
\hline $\begin{array}{l}\text { Analysis of sums over } \\
\text { replicates : }\end{array}$ & & & & & \\
\hline 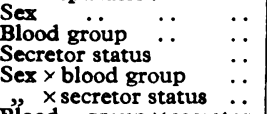 & $\begin{array}{l}1.2515 \\
0.3954 \\
0.0613 \\
0.0874 \\
0.0239\end{array}$ & $\begin{array}{l}1 \\
1 \\
1 \\
1 \\
1\end{array}$ & $\begin{array}{l}1.2515 \\
0.3954 \\
0.0613 \\
0.0874 \\
0.0239\end{array}$ & $\begin{array}{r}48 \cdot 51 \\
15 \cdot 33 \\
2 \cdot 38 \\
3 \cdot 39 \\
0 \cdot 93\end{array}$ & $\begin{array}{l}<0.000,001 \\
<0.0001 \\
<0.2 \\
<0.1\end{array}$ \\
\hline $\begin{array}{l}\text { Blood group } \times \text { secretor } \\
\text { status } \\
\text { Sex and blood } \text { group } \ddot{x}\end{array}$ & 0.0022 & 1 & 0.0022 & 0.09 & - \\
\hline $\begin{array}{l}\text { secretor status } \\
\text { Residual between persons }\end{array}$ & 0.0546 & 1 & 0.0546 & $2 \cdot 12$ & $<0.2$ \\
\hline $\begin{array}{lll}\text { (error) } & \ldots & \ldots\end{array}$ & $20 \cdot 4260$ & 792 & 0.0258 & - & \\
\hline $\begin{array}{l}\text { Analysis within replicates: } \\
\text { Between replicates ... } \\
\text { Replicates and persons }\end{array}$ & $\begin{array}{l}0.0002 \\
0.1254\end{array}$ & $\begin{array}{r}1 \\
799\end{array}$ & $\begin{array}{l}0.0002 \\
0.0002\end{array}$ & 1.0 & \\
\hline Total & $22 \cdot 4279$ & 1,599 & & & \\
\hline
\end{tabular}

From the analysis of variance the following facts emerge: (1) Of all the factors studied, sex has the greatest effect in determining the serum-pepsinogen level. Thus males as a class have a higher mean level $\left(\mathrm{P}<10^{-6}\right)$. (2) The blood-group effect is significant at $\mathrm{P}<0.0001$. In other words, the possibility that the higher overall mean pepsinogen level found in blood group O could have occurred by chance is less than 1 in 10,000. (3) The higher levels noted in the non-secretor phenotypic classes (Table I) are not significant $(P<0.2)$. (4) There are no significant interactions between the items studied. (5) The variance of the experimental error in 800 duplicated serum pepsinogen estimations is 0.0002 and hence the standard deviation is 0.0141 .

Table III shows an analysis of variance of the male and female data. Because of the negligible effect of the error of

\begin{tabular}{|c|c|c|c|c|c|c|}
\hline $\begin{array}{l}\text { Source of } \\
\text { Variation }\end{array}$ & & $\begin{array}{l}\text { Sum of } \\
\text { Squares }\end{array}$ & $\begin{array}{c}\text { Degrees of } \\
\text { Freedom }\end{array}$ & $\begin{array}{c}\text { Mean } \\
\text { Square }\end{array}$ & $\begin{array}{c}\text { Variance } \\
\text { Ratio }\end{array}$ & $\mathbf{P}$ \\
\hline \multicolumn{7}{|c|}{ Males } \\
\hline $\begin{array}{l}\text { Blood group } \\
\text { Secretor } \\
\text { Blood group } \\
\text { Brror } \quad \text { secreto } \\
\end{array}$ & $\begin{array}{c}\because . \\
\ddot{c o r} \\
\cdots \\
\end{array}$ & $\begin{array}{l}0.2136 \\
0.0448 \\
0.0094 \\
4.7527\end{array}$ & \begin{tabular}{r|}
1 \\
1 \\
1 \\
396
\end{tabular} & $\begin{array}{l}0.2136 \\
0.0448 \\
0.0094 \\
0.0120\end{array}$ & $\begin{array}{r}17 \cdot 80 \\
3 \cdot 73 \\
0 \cdot 78\end{array}$ & $\begin{array}{l}<0.001 \\
<0.1 \\
-\end{array}$ \\
\hline Total & . & $5 \cdot 0205$ & 399 & & & \\
\hline \multicolumn{7}{|c|}{ Females } \\
\hline $\begin{array}{l}\text { Blood group } \\
\text { Secretor } \\
\text { Blood group } \times \text { secreto } \\
\text { Error }\end{array}$ & $\begin{array}{l}. . \\
\text { tor } \\
. .\end{array}$ & $\begin{array}{l}0.0279 \\
0.0022 \\
0.0190 \\
5.7087\end{array}$ & \begin{tabular}{r|}
1 \\
1 \\
1 \\
396
\end{tabular} & $\begin{array}{l}0.0279 \\
0.0022 \\
0.0190 \\
0.0144\end{array}$ & $\begin{array}{l}1.94 \\
0.15 \\
1.32\end{array}$ & $\underline{Z}=$ \\
\hline Total & . & $5 \cdot 7578$ & 399 & & & \\
\hline
\end{tabular}

the assay on the results, the mean $\log _{10}$ serum-pepsinogen value for each subject has been used for these computations. The results confirm that the blood-group effect is much greater in males. In neither sex does the secretor effect achieve significance, but it only just fails to reach the $5 \%$ level in the male analysis.

\section{Discussion}

Assuming that the serum-pepsinogen level affords an approximate index of the peptic-cell mass (see introduction), the above results indicate that sex and $A B O$ blood-group genes influence the degree of development of the peptic secretory-cell mass. Thus the mean peptic secretory-cell mass of the stomach, as assessed by the mean serum-pepsinogen level, is greater in males than in females and in group $\mathrm{O}$ than in group A subjects. The blood-group effect is predominantly seen in males, the higher level of serum pepsinogen in group $O$ females not being statistically significant.

The higher serum-pepsinogen level in males is in keeping with previous work on serum pepsinogen (Mirsky et al., 1952; Goidsenhoven et al., 1958) though the degree of significance in this study is far greater and establishes the sex effect beyond doubt. The results are also in agreement with the recent work on the gastric parietal-cell mass (Marks and Shay, 1959). Cox (1952) estimated the average male stomach to contain a parietalcell population of 1.09 billion compared with a female one of 0.82 billion. The work of Ojha and Wood (1950) suggests that the female sex hormones have a depressant action on the gastric secretory mucosa. They gave repeated small doses of stilboestrol over two weeks to cats of both sexes, and showed a progressive reduction in histamine-stimulated acid output.

The reason why the incidence of duodenal ulceration is considerably reduced in females during their reproductive years, and particularly during pregnancy (Clark, 1953), is not known. Possibly the sex hormones influence mucosal resistance, but duodenal ulcer being a disease associated with an increased gastric secretory-cell mass, the lower mean pepsinogen level in healthy females as compared with healthy males suggests that the lower incidence of duodenal ulcer is related to their smaller gastric secretory-cell mass. If the female sex hormones suppress development of the gastric secretory-cell mass, this would explain why the blood-group effect on the serum-pepsinogen level is far less obvious in females, a possible stimulating effect of blood group $\mathrm{O}$ having been suppressed by the female sex hormones.

To turn now to the blood-group effect on the size of the gastric secretory-cell mass as indicated by the serum-pepsinogen level, the above results confirm the initial work of Sievers (1959). The uniformity of the cumulative frequency distribution curves (Figs. 2 and 3 ) shows clearly that the difference in mean serum-pepsinogen level between group $O$ and group $A$ phenotypic classes is not due to the inclusion of undiagnosed or potential duodenal-ulcer subjects, more of whom would be expected in the group $O$ phenotypic class-duodenal-ulcer subjects having a higher mean serum-pepsinogen level than healthy ones (Mirsky et al., 1952). The fact that stomal ulceration appears to have an even closer association with blood group $O$ than does duodenal ulcer (Doll et al., 1960 ; Blegvad, 1960) would seem to suggest a positive stimulating role for the group O genotype on the development of the gastric secretory mucosa, rather than a depressant one for group A genotype.

The finding of no significant difference in maximal histamine-stimulated acid output in duodenal ulcer subjects between the $A B O$ blood group and salivary $A B H$ secretor phenotypes (Brown et al., 1956 ; Ventzke and Grossman, 1962) is not felt to be incompatible with the present results. The large secretory-cell mass of duodenal ulcer is almost certainly the result of multiple factors, and blood-group effect is likely to be inconspicuous, it merely allowing more group $\mathrm{O}$ than group $\mathrm{A}$ subjects to enter the duodenal-ulcer range.

It now remains to consider how the possession of the genetic character of group $\mathrm{O}$ leads to the development of a larger gastric secretory-cell mass, which may be calculated from the present results as being some $10-15 \%$ greater than in group A. A reasonable assumption appears to be that it is the possession of this larger gastric secretory-cell mass which renders group $O$ subjects, whether they are salivary $\mathrm{ABH}$ secretors or nonsecretors, more liable to duodenal ulcer than their group A counterparts. Thus any explanation should explain not only the present experimental results but also the known difference in duodenal-ulcer incidence in group $\mathrm{O}$ and group $\mathrm{A}$ phenotypes (Clarke et al., 1959). 
The possibility of either blood group $\mathrm{H}$ substance stimulating or A substance depressing the in vitro activity of the pepsinogen in serum, and thus resulting in the present experimental findings, is felt to be most improbable. Certainly a similar hypothesis applied to intragastric pepsin activity cannot explain the higher incidence of duodenal ulcer in group $O$ salivary $A B H$ non-secretors than in group $A$ salivary $A B H$ non-secretors (Clarke et al., 1959).

The basic differences between group $\mathrm{O}$ and group $\mathrm{A}$ persons lie both qualitatively and quantitatively in the blood-groupspecific substances (Race and Sanger, 1962). In salivary ABH non-secretors, however, there are virtually no differences in the blood-group mucopolysaccharide content of saliva from group $O$ or group A subjects (see Table IV). This suggests that the effect of blood group $O$ on the gastric mucosa is mediated within the body rather than within the lumen of the stomach, as the blood-group effect persists in non-secretor subjects both in the present experimental findings and in the duodenal ulcer incidence data.

TABLE IV.-Serologically Determined Data on the $A, H$, and Lewis Blood-group Antigen Concentrations in Saliva of Group $O$ and Group A Subjects (Data Taken from Race and Sanger, 1962)

\begin{tabular}{|c|c|c|c|c|c|}
\hline \multirow{2}{*}{$\begin{array}{l}\text { Blood } \\
\text { Group }\end{array}$} & \multirow{2}{*}{$\begin{array}{l}\text { ABH } \\
\text { Salivary } \\
\text { Secretor } \\
\text { Status }\end{array}$} & \multicolumn{4}{|c|}{$\begin{array}{c}\text { Blood-group } \\
\text { Mucopolysaccharide }\end{array}$} \\
\hline & & A & $\mathbf{H}$ & Lea & Leb \\
\hline $\begin{array}{l}\text { O } \\
\text { A } \\
\text { A } \\
\text { A }\end{array}$ & $\begin{array}{l}\text { S } \\
\text { ss } \\
\text { ss }\end{array}$ & $+\frac{\overline{+}}{(+)}$ & $\begin{array}{c}+++ \\
+ \\
(+) \\
(+)\end{array}$ & $\begin{array}{c}t \\
+ \\
+++ \\
+++\end{array}$ & $\begin{array}{l}++ \\
+ \\
\pm\end{array}$ \\
\hline
\end{tabular}

$\mathrm{S}=$ Secretor. $\mathrm{ss} \Rightarrow$ Non-secretor. Le $=$ Lewis substance. $(+)=$ Trace or absent. The rare recurrence of Lewis-negative individuals is ignored.

It is felt that the most likely mechanism whereby the possession of group $\mathrm{O}$ genotype could lead to the development of a greater gastric secretory-cell mass involves a positive role for $\mathrm{H}$-blood-group substance. In contrast to the water-soluble form of $\mathrm{H}$ substance, the alcohol-soluble form exists in a considerably greater concentration in the tissues of both secretor and non-secretor subjects of those phenotypically group $\mathrm{O}$ as compared with those phenotypically group A (Race and Sanger, 1962). Thus a hypothesis that alcohol-soluble $H$ substance via a biochemical intracellular mechanism stimulates the development of the gastric secretory cell mass could explain the experimental findings of this study and also the relation of duodenal ulcer to $\mathrm{ABO}$ blood group wherein group $\mathrm{O}$ subjects have a higher mean serum-pepsinogen level and a greater risk of developing duodenal ulcer than group A subjects, regardless of salivary $\mathrm{ABH}$ secretor status.

While this hypothesis explains the differences in risk between blood group $\mathrm{O}$ and $\mathrm{A}$, in both salivary $\mathrm{ABH}$ secretors and nonsecretors, it does not explain the greatly increased liability of salivary $\mathrm{ABH}$ non-secretors as a whole to duodenal ulcer (Clarke et al., 1959). The experimental results of this study show no significant difference between the mean serum-pepsinogen levels in salivary $\mathrm{ABH}$ secretors and non-secretors, though the nonsecretors have the highest values. It would therefore appear that the $\mathrm{ABO}$ blood group and salivary $\mathrm{ABH}$ secretor genetic influences on the liability to duodenal ulcer act through different mechanisms, that for the $\mathrm{ABO}$ blood-group system being via the gastric secretory mucosa, that for salivary $A B H$ non-secretion being unknown.

Besides the failure to secrete water-soluble $\mathrm{ABH}$ blood-group mucopolysaccharides in saliva and gastric juice, one of the greatest differences between secretor and non-secretor subjects is the large amount of Le $\mathrm{e}^{\mathrm{a}}$ substance produced in the saliva and gastric juice of $\mathrm{ABH}$ non-secretors (see Table IV). But individuals who are genotypically le le produce no Le $\mathrm{e}^{\mathrm{a}}$ substance (Race and Sanger, 1962). Thus in salivary ABH non-secretors who are also of le le genotype, there is no Le substance in the saliva or gastric juice. Ball (1962) investigated the incidence of $\mathrm{Le}^{\mathrm{a}}$-negative individuals in 172 Nigerian negro duodenal-ulcer patients and found that the excess of salivary $A B H$ nonsecretors $(37.2 \%$ as opposed to the $25.3 \%$ expected-P $<0.01$ ) was entirely composed of persons genotypically Le Le or Le le, who, in other words, produced large amounts of Lea substance. This finding would seem to suggest that the increased susceptibility to duodenal ulcer of non-secretors as compared with secretors is related to the large amounts of Lea substance produced in the salivary and gastric secretions. It may be that Lea substance physically protects the duodenal mucosa against acidpepsin aggression less efficiently, but such a physical difference between Lea substance and the other blood-group mucopolysaccharides seems unlikely considering the minor molecular differences. It is conceivable that Le $\mathrm{L}^{\mathrm{a}}$ substance or its degradation products are absorbed and stimulate hyperplasia of the parietal-cell mass. While this is pure speculation, a pointer exists in a recent observation by Evans (1963). He has found that the Le activity of urine is completely dialysable, in contrast to that in saliva, and hence is of small molecular size. Is this Le activity in urine due to the excretion of absorbed degradation products of the large Lea molecule ? Further work is obviously required before an answer on the role of Lea substance in duodenal ulcer will be forthcoming.

Duodenal ulceration is the result of local breakdown of duodenal mucosal resistance in the face of what is usually an increased acid-pepsin aggression. While the possession of blood group $\mathbf{O}$ character is one factor contributing to this increased gastric secretion, environmental factors have the greatest overall role in the aetiology of duodenal ulcer. Obviously the rapid increase in the incidence of duodenal ulcer in the present century (Craig, 1948) can only be due to environmental influences. While these remain obscure food would appear to be a factor worthy of investigation. For instance, do certain foods contain substances capable of stimulating hyperplasia of the gastric peptic and parietal cells ?

\section{Summary}

The serum-pepsinogen levels have been determined by an improved method for 100 subjects (aged 18-35 years) in each of eight phenotypic classes (male and female, blood groups $O$ and $A$, salivary $A B H$ secretor and non-secretor), making a total of 800 subjects in all. Analysis of variance reveals that the mean serum-pepsinogen level is significantly higher in males than in females $\left(P<10^{-6}\right)$ in group $O$ subjects than in group $A$ subjects $(P<0.0001)$. This blood-group effect is more marked in males than in females. The mean serum-pepsinogen level is not significantly higher in salivary $\mathrm{ABH}$ non-secretors than in salivary $\mathrm{ABH}$ secretors.

Survey of the literature suggests that the serum-pepsinogen level probably reflects the size of the gastric secretory-cell mass. Thus the experimental results reveal that the gastric secretory cell mass is probably larger in group $O$ phenotype than in group A phenotype. A hypothesis is advanced that H-bloodgroup substance stimulates the development of the gastric peptic-cell mass, and hence group $O$ subjects, as a class, have a greater gastric peptic secretory potential than do group A subjects. This may well be the reason why group $O$ persons are more susceptible to duodenal ulcer than those of group $A$.

The above research has been carried out with the aid of grants from the Medical Research Committee of the United Liverpool Hospitals, under the chairmanship of Lord Cohen of Birkenhead, and from the Nuffield Foundation. Generous laboratory facilities were provided in the Department of Chemical Pathology of the United Liverpool Hospitals through the courtesy of Dr. W. H. Taylor. I am also indebted to Dr. C. A. Clarke, who suggested the project; to Dr. R. B. McConnell and Dr. D. A. Price Evans for reading and criticizing the M.D. thesis from which the material of this paper is abridged; to Professor P. M. Sheppard for help with statistical analysis; and to Mr. W. T. A. Donohoe, of the Department of Medicine, University of Liverpool, for his expert sero- 
logical work. Mrs. B. Rothwell rendered invaluable computational assistance.

\section{REFERENCES}

Aird, I., Bentall, H. H., Mehigan, J. A., and Roberts, J. A. F. (1954). Brit. med. $7 ., 2,315$.

Ball, P. A. J. (1962). Ibid., 2, 948.

Blegvad, B. (1960). Dan. med. Bull., 7, 72.

Brown, D. A. P., Melrose, A. G., and Wallace, J. (1956). Brit. med. F., 2, 135 .

Clerk, D. H. (1953). Ibid., 1, 1254.

Clarke, C. A., Edwards, J. W., Haddock, D. R. W., Howel-Evans, A. W., McConnell, R. B., and Sheppard, P. M. (1956). Ibid., 2, 725.

Evans, D. A. P., McConnell, R. B., and Sheppard, P. M. (1959). Ibid., 1, 603 .

Cox, A. J. (1952). Arch. Path., 54, 407.

Craig, J. (1948), Brit. med. 7., $2,330$.

Doll, R., Drane, H., and Newell, A. C. (1961). Gut, 2, 352. and Kellock, T. D. (1951). Ann. Eugen. (Lond.), 16, 231. Swynnerton, B. F., and Newell, A. C. (1960). Gut, 1, 31 . Bvans, D. A. P. (1963). Personal communication.
Goidsenhoven, G. van, Wilkoff, L., and Kirsner, J. B. (1958). Gastroenterology, 34, 421.

Hanley, W. B. (1963). M.D. Thesis, University of Liverpool.

Hirschowitz, B. I. (1955). 7. Lab. clin. Med., 46, 568.

Kay, A. W. (1953). Brit. med. ₹., 2, 77.

Køster, K. H., Sindrup, E., and Seele, V. (1955). Lancet, 2, 52.

Marks, I. N., and Shay, H. (1959). Ibid., 1, 1107.

Mirsky, I. A., Futterman, P., Kaplan, S., and Broh-Kahn, R. H. (1952). 7. Lab. clin. Med., 40, i7.

Niederman, J. C., Gilbert, E. C., and Spiro, H. M. (1962). Ann. intern. Med., 56, 564 .

Oiha, K. N., and Wood, D. R. (1950). Brit. F. Pharmacol., 5, 389.

Purohit, G. L., and Shukla, K. C. (1960). Indian ₹. med. Sci., 14, 522.

Race, R. R., and Sanger, R. (1962). Blood Groups in Man, 4th ed. Blackwell, Oxford.

Roberts, J. A. F. (1957). Brit. f. prev. soc. Med., 11, 107.

Ronsky, R., and Skala, I. (1961). Z. Vitamin-, Hormon- u. Fermentforsch., 11, 273.

Sievers, M. L. (1959). Amer. 7. Med., 27, 246.

- and Fischer, G. L. (1957). Amer. ₹. dig. Dis., 2, 363.

Spiro, H. M., Ryan, A. E., and Jones, C. M. (1956). Gastroenterology, 30, 563.

Ventzke, L. E., and Grossman, M. I. (1962). Ibid., 42, 292.

\title{
Gastric Secretion in Hyperthyroidism
}

\author{
M. J. WILLIAMS,* M.R.C.P. ; D. W. BLAIR, † CH.M., F.R.C.S.ED.
}

As early as 1904 Miesowicz noted impaired secretion of acid by the stomach in patients with hyperthyroidism. Since then many studies of gastric secretion in such patients have been undertaken, and a high incidence of achlorhydria has been reported (Moll and Scott, 1927 ; Brown, 1930 ; Lerman and Means, 1932 ; Berryhill and Williams, 1932 ; Wilkinson, 1933 ; Louis and Wills, 1937 ; McElroy et al., 1938 ; Brown et al., 1941). The relative incidence ranged from 12\% (McElroy et al., 1938) to $68 \%$ (Berryhill and Williams, 1932) and hypochlorhydria was frequent in those not achlorhydic. As in most cases acid secretion returned or increased after treatment (Berryhill and Williams, 1932; Wilkinson, 1933; Louis and Wills, 1937), a functional change in the gastric mucosa, possibly related to overactivity of the sympathetic nervous system, was suggested as the cause of impaired acid secretion. No consistent relationship was found between the presence or absence of achlorhydria and the age of the patients or the severity of the disease, but it was thought to be more frequent in those with symptoms of longer duration (Moll and Scott, 1927 ; Wilkinson, 1933 ; Louis and Wills, 1937).

The stimulus to gastric secretion used in these studies was either some variety of test meal and/or conventional doses of histamine, all of which provide inadequate stimulation of the parietal cells (Card et al., 1955 ; Card and Sircus, 1958). The true incidence of achlorhydria in hyperthyroidism cannot therefore be assessed from these previous observations, and, using the augmented histamine test (Kay, 1953), Card and Sircus (1958) stated that no alteration in gastric secretion was found in hyperthyroid patients, but no details were given. More recently Bock and Witts (1963) reported a detailed study of gastric secretion in hyperthyroidism and reached similar conclusions. They initially performed the azuresin ("diagnex") test on 18 patients and then carried out more detailed studies with the augmented histamine test in a further 29. Achlorhydria was found only once in the 47 patients, and the mean total acid output in the 29 patients studied with the augmented histamine test was no different from that reported by Card and Sircus (1960) for normal subjects. In some of their patients,

* Lecturer in Therapeutics, University of Aberdeen.

+ Senior Lecturer in Surgery, University of Aberdeen. however, acid secretion increased after treatment, and they suggested that active thyrotoxicosis inhibited the secretory response of the stomach. They also studied gastric biopsies from 36 patients. The majority showed no abnormality, but there was superficial gastritis in $8(22 \%)$ and atrophic gastritis in $3(8 \%)$.

During the past 18 months we have also used the augmented histamine test to study gastric secretion in hyperthyroidism, being interested in the observed low incidence of peptic ulceration in patients with this condition (Hinton, 1932; Ivy et al., 1950 ; Crile, 1951). Basal acid and pepsin secretions have also been estimated and gastric biopsies were taken in a number of the patients. Our findings differ in several respects from those of Bock and Witts (1963).

\section{Material and Methods}

The ages of the 32 patients (27 females, 5 males) studied ranged from 20 to 63 (mean 45). None had coincident gastrointestinal disease. The diagnosis of hyperthyroidism was confirmed in all cases by discriminant tests of thyroid function, including the clinical diagnostic index (Crooks et al., 1959), estimation of the serum P.B.I. (Farrell and Richmond 1961), and standard radioiodine studies using either ${ }^{131} \mathrm{I}$ or ${ }^{132} \mathrm{I}$. The duration of symptoms was obtained from the patient's history, and the clinical diagnostic index was used as a quantitative measure of severity. ${ }^{1}$ This index has previously been shown to correlate well with other measures of severity such as the B.M.R. and results of radioiodine studies (Crooks et al., 1959).

The haemoglobin was measured in all cases and serum was examined for thyroid autoantibodies by standard techniques to detect coincident autoimmune thyroiditis. The following results were considered significant: precipitin test positive $(t)$ in any titre; tanned-red-cell test if titre was greater than $1 / 25,000$. Lower titres were ignored, as were complement-

${ }^{1}$ Clinical Diagnostic Index : Each symptom and sign in hyperthyroidism is allotted a numerical value and the aggregate score in the individual
case is termed the clinical diagnostic index. The score can also be case is termed the clinical diagnostic index. The score can also be
used in toxic subjects as an index of severity. The original article used in toxic subjects as an index of severity. The original article
should be consulted for full details of the method (Crooks et al., 1959). 